\title{
Influence of Seaweed Extracts (Sargassum dentifolium or Padina gymnospora) on the Growth and Physiological Activities of Faba Bean and Wheat Plants Under Salt Stress
}

\author{
M.A.K. Shaddad ${ }^{1}$, A. A. M. Farghl, ${ }^{2 *}$, H. R. Galal, ${ }^{2}$ and E. \\ A. Hassan, ${ }^{2}$ \\ ${ }^{1}$ Department of Botany, Faculty of Science, Assiut University, \\ Assiut and ${ }^{2}$ Department of Botany, Faculty of Science, South \\ Valley University, Qena, Egypt.
}

\begin{abstract}
7 THE CHANGES of growth and some physiological parameters in faba bean (Vicia. faba L. cv. Masr-1) and wheat (Triticum vulgare L. cv. Sakha-94) treated with $\mathrm{NaCl}$ levels and seeds soaking for $12 \mathrm{hr}$ in $1 \%$ seaweed water extracts from Sargassum dentifolium or Padina gymnospora collected from the red sea, Hurghada, Egypt were studied. Fresh, dry mass and photosynthetic pigments contents (Chl. $a$, Chl. $b$ and Car.) of both plants significantly decreased in response to salt stress. The highest salinity levels $(150$ and $200 \mathrm{mM} \mathrm{NaCl})$ resulted in injurious effects led to death of the tested plants (faba bean and wheat, respectively). Salinity induces a significant decline in the activity of ascorbate peroxidase (APX) of faba bean and peroxidase (POD) of wheat. On the other hand, there was marked increase in the activity of superoxide dismutase (SOD), catalase (CAT), of the two plants, POD of faba bean and APX of wheat compared to untreated plants. Application of $1 \%$ aqueous extract of $S$. dentifolium or P. gymnospora by seed soaking was accompanied by stimulation in growth, photosynthetic pigments and the activity of antioxidant enzymes. The higher activity was observed for extract of $S$. dentifolium. In contrast, treatment with seaweed water extracts resulted in significantly decreased in MDA content, which increased under salinity stress. All the previous findings suggested the possibility that seaweed water extracts may play an important role in increasing plant resistance by stimulating the antioxidant enzyme system which associated with a marked retardation in the MDA content.
\end{abstract}

Keywords: Antioxidant, Sargassum dentifolium, Padina gymnospora; Salinity, Lipid peroxidation.

Abbreviations - APX, ascorbate peroxidase; CAT, catalase; POD, peroxidase; SOD, superoxide dismutase; MDA, malondialdehyde; ROS, reactive oxygen species; LPO, lipid peroxidation; LOX, lipoxygenases; SLF, seaweed liquid fertilizer; ROI, reactive oxygen intermediates.

*Corresponding author's e-mail: farghla@yahoo.com 
Seaweed liquid fertilizers (SLF) will be useful for achieving higher agricultural production, because they are containing growth promoting hormones, trace elements and vitamins (Renuka Bai et al.2011). Among them, Fucus spp., Padina spp., Laminaria spp., Sargassum spp., and Turbinaria spp. are used as biofertilizers in agriculture (Hong et al., 2007). Treatment crops with seaweed liquid fertilizers increased resistance to diseases have been reported (Mercier $e t$ al., 2001; Anisimov et al., 2013.). Seed soaked with marine algal extracts ameliorate adverse effects of salinity on crop plants and used as biofertilizers in agriculture (Shaddad, et al., 2013). Physiologically, many processes are affected by salt stress. However, reduced cell growth, leaf area, biomass and yield are most notable (Shannon, 1997). Salinity affects photosynthesis per unit leaf area indirectly through stomatal closure, and to a smaller extent through direct interference with the photosynthetic apparatus (Netondo et al., 2004; Ehsanzadeh et al., 2009). Stomatal closure minimizes transpiration and this affects chloroplast light-harvesting and energy-conversion system leading to alteration in chloroplast activity (Iyengar and Reddy, 1996). Reduction in chlorophyll content of plants is accompanied by a lower efficiency of PS II and senescence. Another possible factor contributing to decreased photosynthesis is the inhibitory effect of salt stress on the efficiency of translocation and assimilation of photosynthetic products (Ehsanzadeh et al., 2009). In addition, salinity decreases whole plant photosynthesis by restricting leaf area expansion (Netondo et al., 2004; Ehsanzadeh et al., 2009).

Environmental stresses including salinity increased formation of reactive oxygen species (ROS), which degrade important cellular components (Gapińska et al., 2008). Reactive oxygen species (ROS) attack proteins, lipids and nucleic acids, and the degree of damage depends on the balance between formation of ROS and their removal by the antioxidative scavenging systems. Expression of antioxidant defense genes would in turn be triggered to defend the cell against oxidative damage (Menezes-Benavente et al., 2004). Plants are equipped with oxygen radical detoxifying enzymes, such as superoxide dismutase (SOD), catalase (CAT), peroidase (POD) and ascorbate peroxidase (APX) and antioxidant molecules, like ascorbic acid (AA) and reduced glutathione (GSH) to survive under stress conditions (Rahnama \&Ebrahimzadeh, 2005). Lipid peroxidation (LPO) was measured in term of malondialdehyde (MDA) content produced as a result of peroxidation of unsaturated fatty acids (Kukreja et al., 2005). Lipid peroxidation can also be initiated enzymatically by lipoxygenases (LOX) (Axelord et al., 1981) and these enzymes incorporate molecular oxygen into linoleic and linolenic acids to form lipid hydroperoxides (Elkahoui et al., 2005).

Thus, the aim of the present study was to determine the changes of growth, photosynthetic pigments, antioxidant enzymes activity and lipid peroxidation in faba bean and wheat plants. The ameliorative role of seaweed water extracts from Sargassum dentifolium or Padina gymnospora in regulating salt-induced changes in these parameters was also studied.

Egypt. J. Bot., 54, No. 1 (2014) 


\section{Collection of seaweeds}

\section{Material and Methods}

The seaweeds used in the present study were Sargassum dentifolium and Padina gymnospora belonging to the class Phaeophyceae. They were collected from the coastal area of red sea, Hurghada, Egypt during June, 2009, according to (Bhosle et al., 1975).

\section{Experimental design}

Seeds of faba bean (Vicia. faba L. cv.Masr-1) and grains of wheat (Triticum vulgare L. cv. Sakha-94) plants were obtained from the breeding program of Agriculture Research center, Dokky, Cairo, Egypt. Seeds were sterilized with mercuric chloride $(0.1 \%)$ for 5 minutes then were rinsed 3 times with distilled water. The seeds or grains having the same size, colour and weight were chosen for the experimental purpose. Seeds and grains were soaked in $1 \%$ aqueous extract of $S$. dentifolium or P. gymnospora for $12 \mathrm{hr}$. The sterilized seeds or grains as well as those soaked in seaweed extracts were cultivated in pots containing $3 \mathrm{~kg}$ of clay oven dry soil. Eight seeds were sown in each pot and three replicates (planted pots) from each level of $\mathrm{NaCl}$ were considered. The pots were subjected to the desired salinization levels $(0,50,100$ and $150 \mathrm{mM} \mathrm{NaCl})$ in case of faba bean seeds and reached to $200 \mathrm{mM} \mathrm{NaCl}$ in wheat grains. Thereafter, the test plants were daily irrigated with tap water according to the field capacity. The plants were left to grow under the different salinization levels until the end of the experimental period (40 days).

\section{Growth criteria and chemical analysis:}

At the end of experiment (after 40 days), plants were harvested, washed carefully under tap water and dried on a paper towel. The plant fresh weight was recorded. Plants were then dried in an oven at $80{ }^{\circ} \mathrm{C}$ for $48 \mathrm{hr}$, followed by shoot and root dry weights determinations. Photosynthetic pigments (Chl. $a$, Chl. $b$ and Car.) were quantitatively determined spectrophotometrically ("SPECTRONIC ${ }^{\circledR}$ GENESYS ${ }^{\mathrm{TM}}$ 2PC") according to Metzner et al. (1965).

Estimation of some antioxidant enzymes activities: Fresh samples were prepared according to Mukherjee and Choudhuri (1983). Superoxide dismutase (SOD) activity (EC 1.15.1.1) was measured according to the method of Dhindsa and Matowe (1981). Catalase (CAT) activity (EC 1.11.1.6) was assayed according to Havir and Mellate (1987). Peroxidase (POD) activity (EC 1.11.1.7) was determined according to Klapheck et al. (1990). Ascorbate peroxidase (APX) activity (EC 1.11.1.11) was determined from the decrease in absorbance at 290 nm due to oxidized ascorbic acid (Asada and Chen 1992). The level of lipid peroxidation was measured as malondialdehyde (MDA) content using the method of Heath and Packer (1968). 
The data of all experiments were subjected to analysis by the least significant differences test (L.S.D.) using SPSS program.

\section{Results}

$\mathrm{NaCl}$ salinity caused a highly significant decrease in the production of fresh and dry mass in shoots and roots of the tested plants compared to the unsalinized plants. The high salinity levels (150 and $200 \mathrm{mM} \mathrm{NaCl}$ ) induced injurious effects led to death of the (faba bean and wheat) respectively. Accordingly, the faba bean (cv. Masr-1) was more salt sensitive species when compared to wheat (cv. Sakha-94) (Fig.1).

The effects of seaweed water extracts on tested plants grown in the salinized conditions were positive as indicated by the marked stimulatory effect on fresh and dry weight without regard to the conbentration of salinity, which partially alleviated the adverse effect of salinity on growth (Fig.1).

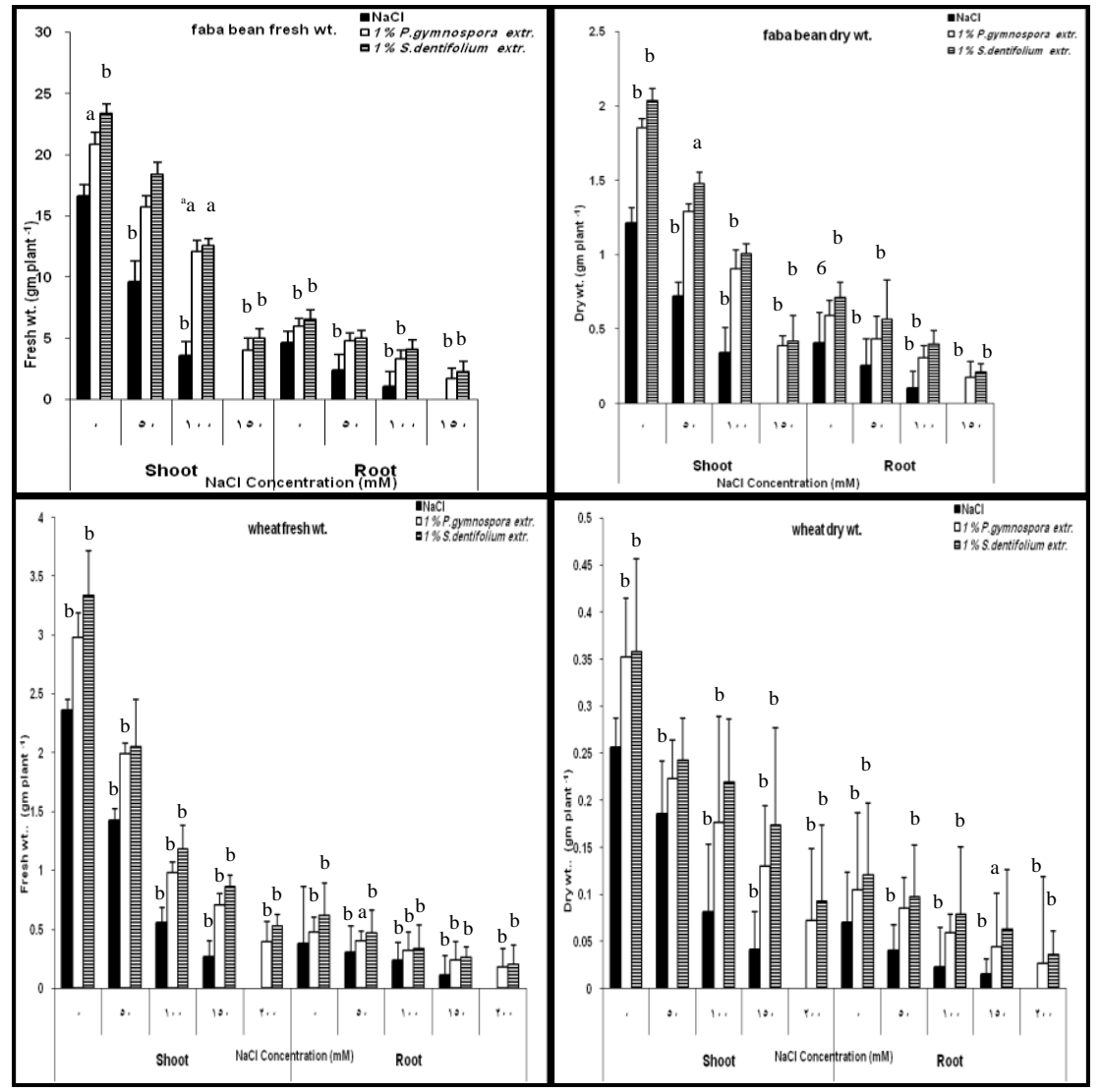

Fig. 1. Fresh and dry weight (gm plant ${ }^{-1}$ ) of faba bean and wheat cultivars affected by $\mathrm{NaCl}$ salinity and seed soaking in $1 \%$ seaweed extracts after 40 days growth.

Egypt. J. Bot., 54, No. 1 (2014) 
Salinity treatment induced an inhibitory effect on the content of the photosynthetic pigments (Chl. $a, \mathrm{Chl} . b$ and Car.) as well as the total pigments in the tested each of plants whatever the salinity level used. Presoaking in $1 \%$ aqueous algal extract resulted in significant increases in pigments content as compared with the salinized plants (Fig.2). Such stimulatory influence on the growth and photosynthetic pigments was much more pronounced in plants treated with the extract of $\mathrm{S}$. dentifolium than plants treated with $P$. gymnospora whatever the salinity level used.

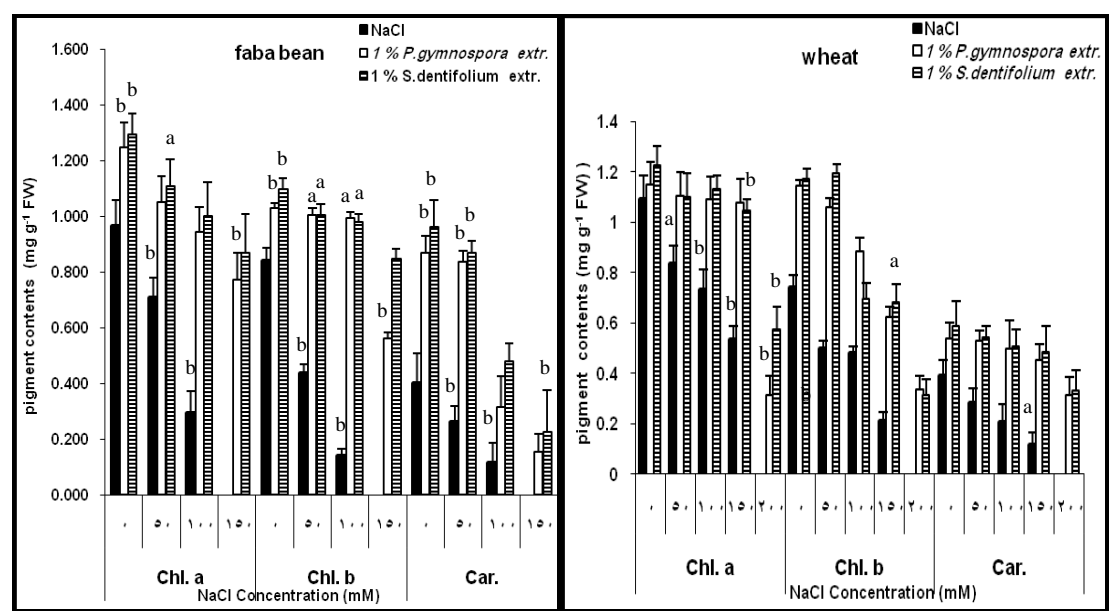

Fig.2. Photosynthetic pigments $\left(\mathrm{mg} \mathrm{g}^{-1} \mathrm{FW}\right)$ of faba bean and wheat affected by $\mathrm{NaCl}$ salinity and seed soaking in $1 \%$ seaweed water extracts after $\mathbf{4 0}$ days growth.

Superoxide dismutase (SOD), Catalase (CAT), peroxidase (POD) and ascorbate peroxidase (APX) enzymes activities were greatly affected to the interactive effect of $\mathrm{NaCl}$ salinity and seeds soaking in $1 \%$ of aqueous seaweed extracts from Sargassum dentifolium or Padina gymnospora. There was a slight increase in the activity of SOD enzyme of faba bean shoots and roots. In wheat, marked and progressive increases in this enzyme activity in both shoot and root under salt stress compared to the absolute control (Tables 1,2 ). $\mathrm{NaCl}$ stress stimulated the activity of CAT of faba bean shoots and roots, while in wheat shoots and roots, CAT activity increased highly significantly with increasing salinity in the soil. CAT activity reached a maximum values (more than 2-fold higher than control) in shoot and root at the level of $150 \mathrm{mM}$ $\mathrm{NaCl}$. In salinized faba bean, POD activity was non-significantly changed with increasing salinity in shoot, while in root organ there was a highly significant increase in the activity of this enzyme by more than 2-fold of the absolute controlat $100 \mathrm{Mm}$ $\mathrm{NaCl}$. On the other hand, there was a gradual reduction in POD activity of wheat 
shoots and roots. This reduction was more pronounced in shoot than in root especially at the higher doses of the salt by reduction percentage was $60 \%$ and $32 \%$ respectively compared to control at $150 \mathrm{mM} \mathrm{NaCl}$ (Tables 1,2$)$. The data show in Tables 1,2 indicated a significant reduction in APX activity of faba bean. On the other hand, there was marked increase in APX activity in both shoot and root of wheat plants under salinity stress. This increase was much more obvious in shoot than in root by increase percent was $78 \%$ and $42 \%$ respectively over control plants (at150 $\mathrm{mM} \mathrm{NaCl}$ ).

Presoaking the seeds in seaweed water extracts improved the activity of all the antioxidant enzymes (SOD, CAT, POD and APX) in both faba bean and wheat plants compared to the corresponding salinized plants. The higher activity was observed for extract of Sargassum dentifolium.

TABLE 1. Superoxide dismutase (SOD), Catalase (CAT), Peroxidase (POD) and ascorbate peroxidase (APX) activity [unit $\mathrm{min}^{-1} \mathrm{~g}^{-1} \mathrm{FW}$ ] of wheat affected by $\mathrm{NaCl}$ salinity and seed soaking in $1 \%$ seaweed water extracts after 40 days growth.

\begin{tabular}{|c|c|c|c|c|c|c|c|c|c|}
\hline \multirow{2}{*}{ Treatments } & \multirow{2}{*}{$\begin{array}{l}\mathrm{NaCl} \\
(\mathrm{mM})\end{array}$} & \multicolumn{4}{|c|}{ Shoots } & \multicolumn{4}{|c|}{ Roots } \\
\hline & & SOD & CAT & POD & APX & SOD & CAT & POD & APX \\
\hline \multirow{5}{*}{$\begin{array}{c}\text { Reference } \\
\text { control }\end{array}$} & 0 & 3.222 & 2.111 & 19.620 & 1.113 & 3.778 & 4.778 & 8.520 & 0.910 \\
\hline & 50 & 4.044 & $3.556^{\mathrm{a}}$ & 17.333 & 1.406 & 4.333 & 5.444 & 7.800 & $1.077^{\mathrm{a}}$ \\
\hline & 100 & $4.889^{b}$ & $5.00^{\mathrm{b}}$ & $11.060^{b}$ & $1.786^{\mathrm{b}}$ & $4.944^{\mathrm{b}}$ & $9.333^{\mathrm{b}}$ & $6.660^{\mathrm{a}}$ & $1.200^{\mathrm{b}}$ \\
\hline & 150 & $5.056^{\mathrm{b}}$ & $7.00^{\mathrm{b}}$ & $7.790^{\mathrm{b}}$ & $1.987^{\mathrm{b}}$ & $5.444^{\mathrm{b}}$ & $10.889^{\mathrm{b}}$ & $5.760^{\mathrm{b}}$ & $1.30^{\mathrm{b}}$ \\
\hline & 200 & \multicolumn{2}{|c|}{$\mathrm{IE}$} & \multicolumn{2}{|c|}{$\mathrm{IE}$} & \multicolumn{2}{|c|}{$\mathrm{IE}$} & \multicolumn{2}{|c|}{$\mathrm{IE}$} \\
\hline \multirow{5}{*}{$\begin{array}{l}\text { Padina } \\
\text { gymnospora } \\
\text { extract + }\end{array}$} & 0 & $4.333^{\mathrm{a}}$ & $5.778^{\mathrm{b}}$ & $23.833^{\mathrm{a}}$ & $2.450^{\mathrm{b}}$ & $5.444^{b}$ & $6.778^{\mathrm{a}}$ & $16.390^{\mathrm{b}}$ & $1.797^{\mathrm{b}}$ \\
\hline & 50 & $5.056^{\mathrm{b}}$ & $7.111^{\mathrm{b}}$ & 21.243 & $2.557^{\mathrm{b}}$ & $6.000^{\mathrm{b}}$ & $9.333^{b}$ & $14.223^{\mathrm{b}}$ & $1.975^{\mathrm{b}}$ \\
\hline & 100 & $5.389^{\mathrm{b}}$ & $8.111^{\mathrm{b}}$ & 17.027 & $2.660^{\mathrm{b}}$ & $6.333^{b}$ & $13.667^{\mathrm{b}}$ & $12.910^{\mathrm{b}}$ & $2.022^{\mathrm{b}}$ \\
\hline & 150 & $5.556^{\mathrm{b}}$ & $8.222^{\mathrm{b}}$ & $13.380^{b}$ & $2.990^{\mathrm{b}}$ & $6.778^{b}$ & $15.333^{\mathrm{b}}$ & $12.233^{\mathrm{b}}$ & $2.167^{b}$ \\
\hline & 200 & $5.778^{\mathrm{b}}$ & $8.889^{\mathrm{b}}$ & $11.280^{\mathrm{b}}$ & $3.181^{\mathrm{b}}$ & $7.333^{b}$ & $16.111^{\mathrm{b}}$ & $11.187^{\mathrm{b}}$ & $2.233^{\mathrm{b}}$ \\
\hline \multirow{5}{*}{$\begin{array}{l}\text { Sargassum } \\
\text { dentifolium } \\
\text { extract + }\end{array}$} & 0 & $4.556^{\mathrm{a}}$ & $6.000^{\mathrm{b}}$ & $27.330^{\mathrm{b}}$ & $2.526^{\mathrm{b}}$ & $6.111^{\mathrm{b}}$ & $9.222^{\mathrm{b}}$ & $16.503^{b}$ & $1.843^{\mathrm{b}}$ \\
\hline & 50 & $5.444^{\mathrm{b}}$ & $7.222^{b}$ & $23.667^{\mathrm{a}}$ & $2.733^{\mathrm{b}}$ & $6.333^{b}$ & $13.556^{\mathrm{b}}$ & $15.990^{\mathrm{b}}$ & $1.942^{b}$ \\
\hline & 100 & $5.333^{\mathrm{b}}$ & $9.222^{\mathrm{b}}$ & 21.310 & $2.900^{\mathrm{b}}$ & $6.889^{b}$ & $14.444^{\mathrm{b}}$ & $15.300^{\mathrm{b}}$ & $2.240^{\mathrm{b}}$ \\
\hline & 150 & $5.389^{\mathrm{b}}$ & $9.556^{\mathrm{b}}$ & 15.763 & $3.057^{\mathrm{b}}$ & $7.222^{b}$ & $15.000^{\mathrm{b}}$ & $14.027^{\mathrm{b}}$ & $2.255^{\mathrm{b}}$ \\
\hline & 200 & $5.833 \mathrm{~b}$ & $10.222^{\mathrm{b}}$ & $13.097^{\mathrm{b}}$ & $3.252^{\mathrm{b}}$ & $8.000^{\mathrm{b}}$ & $16.556^{\mathrm{b}}$ & $11.693^{\mathrm{b}}$ & $2.500^{\mathrm{b}}$ \\
\hline \multirow[t]{2}{*}{\begin{tabular}{|l|} 
L.S.D \\
\end{tabular}} & $5 \%$ & 0.872 & 1.171 & 3.882 & 0.442 & 0.777 & 1.913 & 1.519 & 0.198 \\
\hline & $1 \%$ & 1.174 & 1.577 & 5.227 & 0.595 & 1.047 & 2.577 & 2.046 & 0.267 \\
\hline
\end{tabular}

Egypt. J. Bot., 54, No. 1 (2014) 
TABLE 2. Superoxide dismutase (SOD), Catalase (CAT), Peroxidase (POD) and ascorbate peroxidase (APX) activity [unit min $^{-1} \mathrm{~g}^{-1} \mathrm{FW}$ ] of faba bean affected by $\mathrm{NaCl}$ salinity and seed soaking in $1 \%$ seaweed water extracts after 40 days growth.

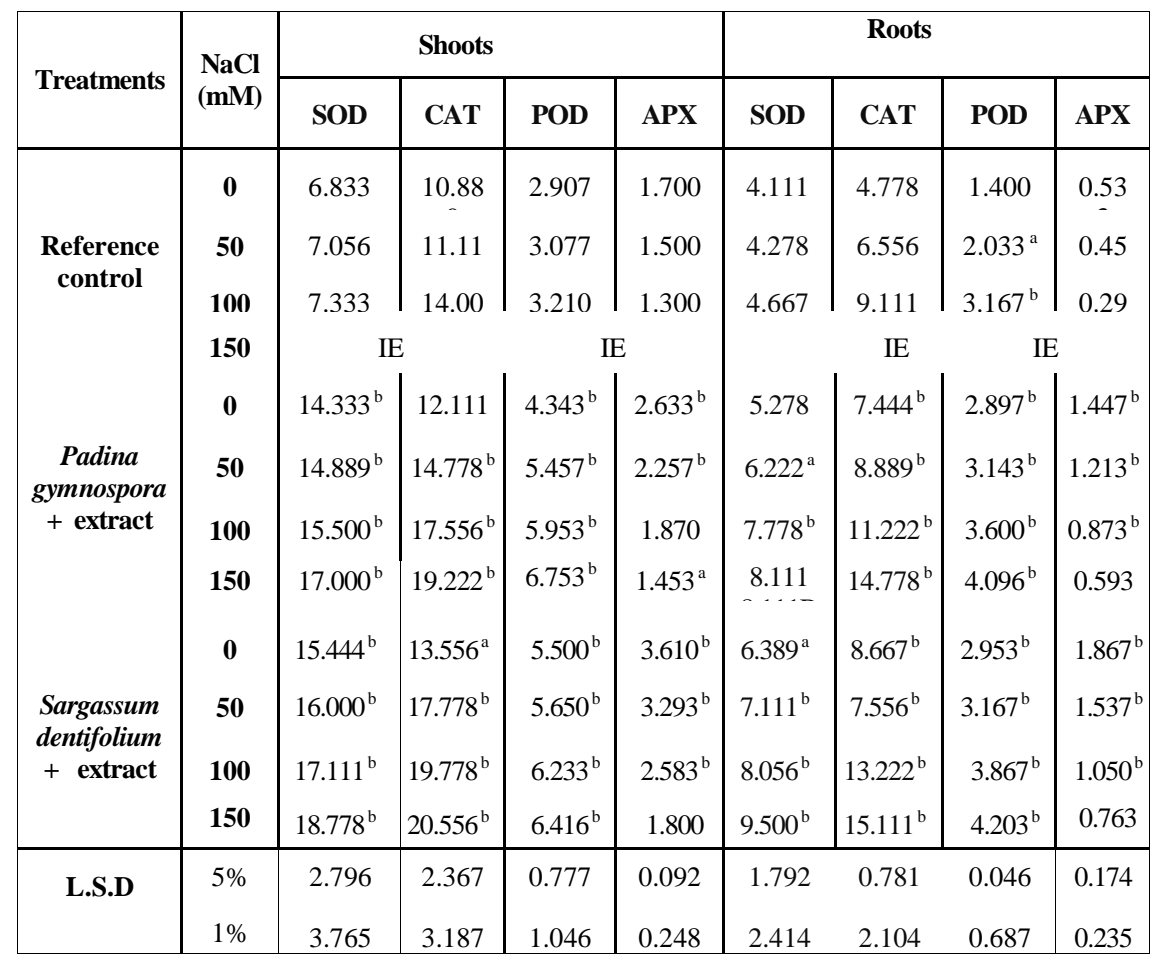

Regardy there was a highly significant accumulation in MDA content as increasing salt in the soil in shoots and roots of faba bean and wheat cultivars. This accumulation was more pronounced in faba bean than in wheat plants. At $100 \mathrm{mM} \mathrm{NaCl}$, MDA content was the highest by about 3.5-fold and 2-fold of the control value in shoot and root of faba bean respectively.

Generally, algal extracts pre-treatment significantly decreased MDA content in wheat and faba bean plants and could successfully alleviate the harmful effect of salinity on MDA content of the two plants. The highest decrease in the MDA content was recorded for S.dentifolium extract that decreased MDA content in shoot of faba bean from 159 to $49 \mathrm{nmol}^{-1} \mathrm{~g}^{-1}$ fresh weight and in root of faba bean from 93 to $34 \mathrm{nmol}^{-1} \mathrm{~g}^{-1}$ fresh weight (at $100 \mathrm{mM} \mathrm{NaCl}$ ) (Table 3). 
TABLE 3. Malondialdehyde (MDA) content $\left(\mathrm{nmol} \mathrm{g}^{-1} \mathrm{FW}\right)$ of wheat cultivar and faba bean affected by $\mathrm{NaCl}$ salinity and seed soaking in $1 \%$ seaweed water extracts after 40 days growth.

\begin{tabular}{|c|c|c|c|c|c|}
\hline \multirow{2}{*}{ Treatments } & \multirow{2}{*}{$\begin{array}{l}\mathrm{NaCl} \\
(\mathrm{mM})\end{array}$} & \multicolumn{2}{|c|}{ wheat cultivar } & \multicolumn{2}{|c|}{ faba bean } \\
\hline & & Shoots & Roots & Shoots & Roots \\
\hline \multirow{5}{*}{$\begin{array}{c}\text { Reference } \\
\text { control }\end{array}$} & 0 & 107.980 & 75.430 & 45.131 & 44.774 \\
\hline & 50 & $168.720^{\mathrm{b}}$ & $94.030^{\mathrm{a}}$ & $88.422^{b}$ & $64.778^{b}$ \\
\hline & 100 & $171.321^{b}$ & $107.470^{\mathrm{b}}$ & $159.567^{\mathrm{b}}$ & $93.730^{\mathrm{b}}$ \\
\hline & 150 & $175.447^{b}$ & $120.897^{b}$ & IE & IE \\
\hline & 200 & IE & IE & IE & IE \\
\hline \multirow{5}{*}{$\begin{array}{c}\text { Padina } \\
\text { gymnospora+ } \\
\text { extract }\end{array}$} & 0 & $64.403^{b}$ & 59.560 & 40.474 & $35.627^{b}$ \\
\hline & 50 & $70.487^{b}$ & 63.330 & 50.822 & 42.220 \\
\hline & 100 & $74.347^{\mathrm{b}}$ & 70.330 & $55.681^{\mathrm{a}}$ & 45.883 \\
\hline & 150 & $87.670^{\mathrm{b}}$ & 83.700 & $60.010^{\mathrm{b}}$ & $55.400^{\mathrm{b}}$ \\
\hline & 200 & $96.460^{\mathrm{a}}$ & $96.809^{a}$ & IE & IE \\
\hline \multirow{5}{*}{$\begin{array}{c}\text { Sargassum } \\
\text { dentifolium }+ \\
\text { extract }\end{array}$} & 0 & $60.000^{\mathrm{b}}$ & $40.030^{\mathrm{b}}$ & $21.709^{b}$ & $21.453^{b}$ \\
\hline & 50 & $71.847^{b}$ & $45.470^{b}$ & 37.211 & $30.033^{b}$ \\
\hline & 100 & $78.070^{\mathrm{b}}$ & $50.630^{\mathrm{b}}$ & 49.083 & $34.297^{b}$ \\
\hline & 150 & $84.847^{\mathrm{b}}$ & $75.314^{\mathrm{b}}$ & 51.188 & 44.417 \\
\hline & 200 & $94.513^{\mathrm{a}}$ & 79.905 & IE & IE \\
\hline \multirow{2}{*}{ L.S.D } & $5 \%$ & 10.287 & 16.980 & 8.067 & 6.557 \\
\hline & $1 \%$ & 13.854 & 22.867 & 10.864 & 8.831 \\
\hline
\end{tabular}

Means values in each column which are significantly different $(\mathrm{P}=0.05)$ are followed by a letter and the highly significantly different $(\mathrm{P}=0.01)$ are followed by b letter as compared to control $(0.0 \mathrm{NaCl})$. IE injurious effects and the plant failed to survive.

\section{Discussion}

Marine algal extract plays an important role in elicit a biotic stress tolerance in plants and that the bioactive substances derived from seaweeds impart stress tolerance and enhance plant performance (Wajahatullah et al., 2009) and considerable interests have focused on seaweed liquid fertilizer (SLF) due to its ability to exhibit enhanced salt tolerance (Mancuso et al., 2006).

The results obtained in the present work clearly demonstrated that the values of growth parameters (fresh \& dry weight) of the test plants were generally lowered by increasing salinity. This reduction was more obvious in faba bean than wheat plant. Root growth was less affected than shoot growth especially in case of wheat plants. 
The retardation in growth might either be caused by a reduced ability to adjust osmotically as a result of saturation of the solute uptake system, or because of excessive demand on the energy requirements of such systems (Khan et al., 2000).

The biosynthesis of pigments (Chl.a, Chl.b and Car.) was substantially affected by the different salt levels and the response different between faba bean and wheat plants. The results obtained in this study are in agreement with those of Hameed and Ashraf, (2008).

The decrease in chlorophyll might be attributed to increased chlorophyllase activity (Jaleel et al. 2008). It has also been reported that $\mathrm{Cl}^{-}$may be more injurious than $\mathrm{Na}^{+}$, causing leaf chlorosis in several plant species (Alaoui-Sossé et al., 1998).

Seaweed water extracts from S.dentifolium or P. gymnospora used in this work may act as growth stimulant which can play a role in reversing the effect of $\mathrm{NaCl}$ on metabolic activity relevant to growth through enhancing cell division and/or cell enlargement (Arumugam et al. 2008: Mooney and Van Staden, 1986). In addition, the growth enhancing potential of the seaweed water extract might be attributed to the presence of macro and micronutrients (Shaddad et al., 2013: Sathya et al., 2010).

Soaking the seeds in marine algal extracts in most cases, did not only alleviate the inhibitory effect of salt stress on the biosynthesis of photosynthetic pigments, but also induced a significant stimulatory effect greater than estimated in control plants, a response which may be contributed directly to the effectiveness of photosynthetic apparatus and in some way can alter plant productivity. The results obtained in this study are in agreement with those of (Blunden et al., 1997: Sathya et al., 2010), also (Thirumaran et al., 2009) found that Ascophyllum nodosum and Rosenvingea intricata increased the photosynthetic pigments in cluster bean. According to the result increase in the photosynthetic pigments of wheat and faba bean plants may be due to the presence of magnesium which is the chief constituent for chlorophyll synthesis (Kalaivanan et al., 2012).

The hypothesis that antioxidant enzymes are critical components in preventing oxidative stress in plants is based on several lines of evidence. (a) The activity of one or more of these enzymes is generally increased in plants exposed to stressful conditions, and this elevated activity correlates with increased stress tolerance. (b) Pretreatment of plants under one form of stress can increase tolerance for a different stress. This phenomenon is known as cross tolerance. (c) Plant lines selected for resistance to reactive oxygen intermediates (ROI) have increased levels of one or more of these enzymes and can also exhibit cross-tolerance (Gressel and Galun, 
1994). These observations indicate that exposure to environmental stress can stimulate plants to enhance their ROI scavenging systems and this enhancement can apparently provide generalized stress protection. Our results coincide with the previously mentioned ones on that salinity treated plants reported a marked increase, in most levels of salinity in SOD, CAT activities in the shoots and roots of the tested plants. This increase was much more obvious in wheat cv. Sakha-94 (tolerant genotype) than faba bean cv. Masr-1(sensitive genotype). This increase might be chare in the protection of these plants from oxidative stress (Seyed et al., 2011: Sairam et al., 2005).

Peroxidase (POD) behaved differentially in the two tested plants, that while the POD activity decreased in shoots and roots of wheat, the opposite event was obtained in faba bean. The increase in POD activity suggests an accelerated production in active oxygen species in the tissues (Okuda et al., 1991). The activity of APX varied significantly between faba bean and wheat plants that while the activity of APX enzyme increased in wheat it decreased in faba bean plants. The marked increase in APX activity might reduce the elevated $\mathrm{H}_{2} \mathrm{O}_{2}$ concentration and increased the salt tolerance in wheat (Sairam et al., 2005).

The improved protection in wheat plants may reflect a more efficient antioxidant enzymes as evidence of a higher activity CAT, and APX enzymes. However the higher MDA content in faba bean plants appeared to be correlated with a lower activity of CAT, and APX enzymes, accordingly the lower MDA content and higher activity of the most antioxidant enzymes in wheat than for faba bean plants under salt stress was better able to curtail lipid peroxidation (Esfandiari et al., 2007).

Thereafter it can be pointed out that the variation in the activity of the antioxidant enzyme among the two plants might be used as a suitable marker for the differences in salt tolerance between these tested plants (Durmus and Kadioglu, 2005). This was confirmed with the data of MDA content that, while MDA content increased by $253 \%$ and $109 \%$ of absolute control in shoot and root of faba bean respectively (at $100 \mathrm{mM} \mathrm{NaCl}$ ), the corresponding increase in MDA content in wheat was only about $60 \%$ in both shoot and root (at $150 \mathrm{mM} \mathrm{NaCl}$ ) which indicated that, faba bean shoot is more salt sensitive than root, while in wheat, the salt tolerance of shoot and root seemed to be more or less similar.

Exogenous brown algae, S.dentifolium or $P$. gymnospora extract generally improved the activity of antioxidant enzymes (SOD, CAT, APX and POD) in the shoots and roots of the two tested cultivars compared to the corresponding salinized plants, which associated with a marked retardation in the content of MDA, which in turn decreased membrane damage, this improved the growth criteria and the survival of these cultivars. The lower MDA content indicates that the plants treatments with seaweed extracts are more tolerant to oxidative stress under salinity conditions (Abd El-Baky et al., 2008).

Egypt. J. Bot., 54, No. 1 (2014) 
In conclusion, application of seaweed water extracts significantly increased growth, photosynthetic pigments and the activity of SOD, CAT, POD, and APX. On the other hand, treatment by seaweed extracts resulted in a decrease in MDA compared to plants treated with salinity. Marine algal extracts may act to alleviate salinity stress in faba bean and wheat plants by decreasing permeability of plasma membranes and membrane lipid peroxidation, and by maintaining membrane integrity and function.

\section{References}

Abd El-Baky, H. H., Hussein, M. M. and El-Baroty, G. S. (2008) Algal extracts improve antioxidant defense abilities and salt tolerance of wheat plant irrigated with sea water. Afr. J. Biochem. Res., 2 (7), $151-164$.

Alaoui-Sossé, B., Sehmer, L., Barnola P. and Dizengremel, P. (1998) Effect of $\mathrm{NaCl}$ salinity on growth and mineral partitioning in Quercus robur L., a rhythmically growing species, Trees, 12, 424-430.

Anisimov, M.M., Chaikina, E.L., Klykov, A.G. and Rasskazov, V.A. (2013) Effect of seaweeds extracts on the growth of seedling roots of buckwheat (Fagopyrum esculentum Moench) is depended on the season of algae collection. Agric.Sci. Devel., 2(8), 67-75.

Arumugam, R., Anantharaman, P., Thirumaran, G. and Balasubramanian, T. (2008) Effect of seaweed extract from Sargassum wightii on Vigna unguiculata (L.) Walp. var. Pusa 151. Seaweed Res. Utiln., 30 (special issue): 233-239.

Asada, K. and Chen, G. (1992) On activation of ascorbate peroxidase by thiols requires hydrogen peroxide. Plant Cell Physiol., 33, 117-123.

Axelord, B., T.M. Cheesbrough, and Laakso, S. (1981) Lipoxygenase from soybeans. Methods in Enzymology, 71, 441- 451.

Bhosle, N.B., Untawale, A.G. and Dhargalkar V.K. (1975) Effect of seaweed extracts on the growth of Phaseolus vulgaris L. Indian J. Mar. Sci., 4, 207-210.

Blunden, G., Jenkins, T. and Wan, L.Y. (1997) Enhanced leaf chlorophyll levels in plants treated with seaweed extracts. J. Appl. Phycol., 8(6), 535-543.

Dhindsa, R.S. and Matowe, W. (1981) Drought tolerance in two mosses: correlated with enzymatic defense against lipid peroxidation. J. Exp. Bot., 32, 79-91.

Egypt. J. Bot., 54, No. 1 (2014) 
Durmus, N. and Kadioglu, A. (2005) Reduction of paraguat toxicity in maize leaves by benzyladenine. Acta Biol. Hung, 56, 97-107.

Ehsanzadeh, P., Nekoonam, M. S., Azhar, J.N., Pourhadian, H. and Shaydaee, S. (2009) Growth, chlorophyll, and cation concentration of tetraploid wheat on a solution high in sodium chloride salt: Hulled versus free-threshing genotypes. J. Plant Nutr., 32, 58-70.

Elkahoui, S., Hernandez J., Abdelly, A. C. ,Ghrir, R. and F. Limam. (2005). Effect of salt on lipid peroxidation and antioxidant enzyme activities of Catharanthus roseus suspension cells. Plant Science, 168, 607- 613.

Esfandiari, E., Shekari, F., Shekari, F. and Esfandiari, M. (2007) The effect of salt stress on antioxidant enzymes' activity and lipid peroxidation on the wheat seedling. Not. Bot. Hort. Agrobot. Cluj., 35(1), 48-56.

Gapińska, M., Sklodowska, M. and Gabara, B. (2008) Effect of short- and long-term salinity on the activities of antioxidative enzymes and lipid peroxidation in tomato roots. Acta Physiol. Plant, 30, 11-18.

Gressel J. and Galun, E. (1994) In: "Genetic controls of Photooxidative tolerance". Foyer, CH Mullineaux, PM (Ed.), causes of photooxidative stress and amelioration of defense systems in plants. CRC Press, Boca Raton, FL, pp 237-274.

Hameed, M. and Ashraf, M. (2008) Physiological and biochemical adaptation of Cynodon dactylon (L.) pers. From the salt range (Pakistan) to salinity stress. Flora, 203, 683-694.

Havir, E.A. and Mellate, N.A. (1987) Biochemical and developmental characterization of multiple forms of catalase in tobacco leaves. Plant Physiol., 84, 450-455.

Heath, R.L. and Packer, L. (1968) Photoperoxidation in isolated chloroplast. I. Kinetics and stiochiometry of fatty acid peroxidation. Arch. Bioch. Biophys, 125,189-198.

Hong, D.D., Hief, H.M. and Son, P.N. (2007) Seaweeds from Vietnam used for functional food, medicine and biofertilizer. J. Appl. Phycol., 19, 817- 826.

Iyengar, E.R. and Reddy, M.P. (1996) In: "Photosynthesis in Highly Salt-Tolerant Plants". pesserkali, M. (Ed.), Handbook of photosynthesis, Marshal Dekar, Baten Rose, USA. 897- 909.

Jaleel, C. A., Manivannan, P., Sankar, B., Kishorekumar, A. and Panneerselvam, R. (2008) Salt stress mitigation by calcium chloride in Phyllanthus amarus. Acta Bot. Croat., 67, 53- 62.

Egypt. J. Bot., 54, No. 1 (2014) 
Kalaivanan, C., Chandrasekaran, M. and Venkatesalu, V. (2012) Effect of seaweed liquid extract of Caulerpa scalpelliformis on growth and biochemical constituents of black gram (Vigna mungo (L.) Hepper). Phykos., 42 (2), 46-53.

Khan, M. A., Ungar, I. A. and Showalter, A. M. (2000) Effects of salinity on growth, water relations and ion accumulation in the subtropical perennial halophyte Atriplex griffithii var stocksii. Ann. Bot., 85, 225-232.

Klapheck, S., Zimmer, I. and Cosse, H. (1990) Scavenging of hydrogen peroxide in endosperm of Ricinus communis by ascorbate peroxidase. Plant Cell Physiol., 31, 1005-1013.

Kukreja, S., Nandwal, A.S., Kumar, N., Sharma, S.K., Unvl, V. and Sharma, P.K. (2005) Plant water status, $\mathrm{H}_{2} \mathrm{O}_{2}$ scavenging enzymes, ethylene evolution and membrane integrity of Cicer arietinum roots as affected by salinity. Biol. Plant., 49, 305-308.

Mancuso, S., Azzarello, E., Mugnai, S., Briand, X., (2006) Marine bioactive substances (IPA extract) improve foliar ion uptake and water tolerance in potted Vitis vinifera plants. Adv. Hort Sci., 20, 156-161.

Menezes-Benavente, L., S. P. Kernodle, Margis-Pinheiro, M. and Scandalios, J. G. (2004) Salt induced antioxidant metabolism defenses in maize (Zea mays L.) seedlings. Redox Report 9, 29-36.

Mercier, L., Lafitte, C., Borderies, G., Briand, X., Esquerré-Tugayé,M.T. and Fournier, J. (2001) The algal polysaccharide carrageenans can act as an elicitor of plant defence. New Phytol., 149, 43-51.

Metzner, H., Rau, H. and Senger, H. (1965) To synchronsiser bakeit investigations of individual pigment-deficiency mutants of Chlorella. Planta, 65, 186-194.

Mooney, P.A. and Van Staden, J. (1986) Algae and cytokinins. J. Plant Physiol., 123, 1-21.

Mukherjee, S.P. and Choudhuri, M.A. (1983) Implications of water stress-induced changes in the levels of endogenous ascorbic acid and hydrogen peroxide in Vigna seedlings. Plant Physiol., 58, 166-170.

Netondo, G. W., Onango, J. C. and Beck, E. (2004) Sorghum and salinity: II. Gas exchange and chlorophyll fluorescence of sorghum under salt stress. Crop Science, 44, 806-811. 
Okuda, T., Matsuda, Y., Yamanaka, A. and Sagisaka, S. (1991): Abrupt increases in the level of hydrogen peroxide in leaves of winter wheat is caused by cold treatment. Plant Physiol., 97, 1265-1267.

Rahnama, H. and Ebrahimzadeh, H. (2005) The effect of $\mathrm{NaCl}$ on antioxidant enzyme activities in potato seedlings. Biol. Plant, 49, 93- 97.

Renuka Bai, N., Mary Christi, R. and Christy Kala, T. (2011) Effect of seaweed concentrate of padina pavonia on the growth and yield of a pulse crop. Plant Arch, 11, 117-120.

Sairam, R.K., Srivastava, G.C., Agarwal, S. and Meena, R.C. (2005) Differences in antioxidant activity in response to salinity stress in pyridoxine. Plant and Soil, 122,177-183.

Sathya, B. Indu, H. Seenivasan, R. and Geetha, S. (2010) Influence of seaweed liquid fertilizer on the growth and biochemical composition of legume crop, cajanus cajan (1.) Mill sp. J. Phytol, 2(5), 50-63.

Seyed, M., Bahram, A., Mohammad, Z., Rasool, A. and Majid, K. (2011) Superoxide dismutase (SOD) activity in $\mathrm{NaCl}$ stress in salt-sensitive and salt-tolerance genotypes of Colza (Brassica napus L.). Middle-East J. Sci. Res., 7 (1), 7-11.

Shaddad, M. A., Farghl, A.A., Galal, H. R. and Hassan, E. A. (2013) Using marine algae extracts as bio-fertilizer to alleviate saline injury in crop plants. Egypt. J. Biotechnol., 44,16-36.

Shannon, M. C. (1997) Adaptation of plants to salinity. Adv. Agron, 60, 75-120

Thirumaran, G., Arumugam, M., Arumugam, R. and Anantharaman, P. (2009) Effect of seaweed liquid fertilizer on growth and pigment concentration of Cyamopsis tetrogonolaba (L.) Taub. Am-Euras. J. Agron., 2 (2), 50-56.

Wajahatullah, K., Usha, P.R., Sowmyalakshmi, S., Mundaya, N. J., Prasanth, R., Mark, D. H., Alan, T.C., James, S.C., Jeff, N. and Balakrishan, P. ( 2009 ) seaweed extracts as biostimulants of plant growth and development. J. Plant Growth Regul., 28, 386-399. 


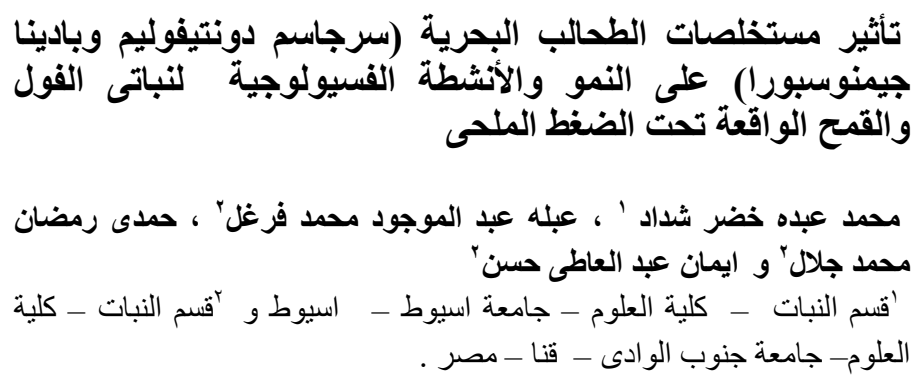

في هذا البحث تم دراسة التغيرات التي تطرأ على النمو و بعض الأنثطة

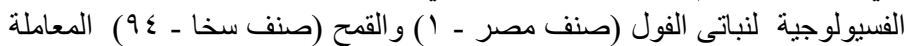

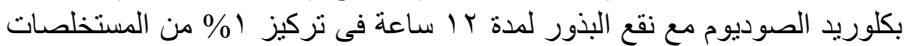
المائية لطحلبى Sargassum dentifolium or Padina gymnospora تم جمعها من البحر الأحمر, الغردقة, مصر. لوحظ نقص واضئ واضح في الوزن الطاز

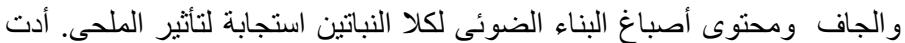

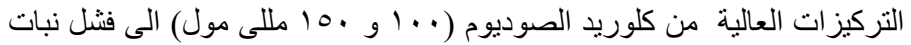

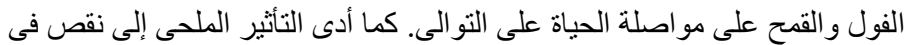

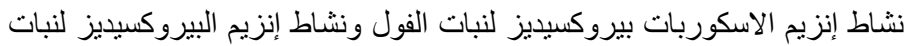

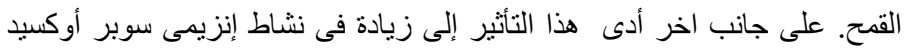

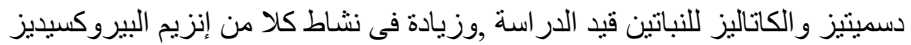

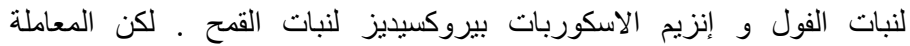

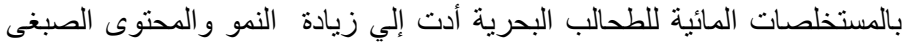

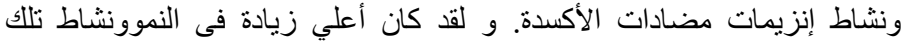

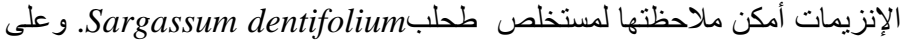

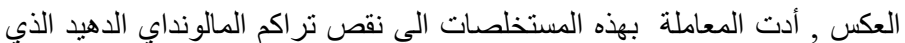
زاد تحت تأثير الملوحة. مما سبق يتضح أن المستخلصات المائية للطحالب البحرية بإمكانها أن تلعب دور هام فى زيادة مقاومة النبات للضغط الملحى عن طريق تلتيبيه

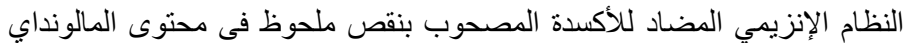

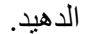

